University of Wollongong

Research Online

Faculty of Engineering and Information

Faculty of Engineering and Information

Sciences - Papers: Part A

Sciences

$1-1-2013$

Effect of annealing on properties of carbonaceous materials. Part II: porosity and pore geometry

Xing Xing

University of New South Wales, x.xing@unsw.edu.au

Guangqing Zhang

University of Wollongong, gzhang@uow.edu.au

Mark Dell'Amico

CSIRO Energy Technology, Australia

George Ciezki

Tasmanian Electro Metallurgical Company, George.Ciezki@BHPBilliton.com

Qingbo Meng

Sinosteel Anshan Research Institute of Thermo-Energy Co., Ltd, meng123qb@sina.com

See next page for additional authors

Follow this and additional works at: https://ro.uow.edu.au/eispapers

Part of the Engineering Commons, and the Science and Technology Studies Commons

Research Online is the open access institutional repository for the University of Wollongong. For further information contact the UOW Library: research-pubs@uow.edu.au 


\title{
Effect of annealing on properties of carbonaceous materials. Part II: porosity and pore geometry
}

\author{
Abstract \\ The pore structure of carbonaceous materials was studied using image analysis. The effect of annealing \\ on the porosity and pore geometry of cokes, chars, and pyrolyzed coals (laboratory chars) was examined \\ in the temperature range of $973 \mathrm{~K}$ to $1773 \mathrm{~K}$ (700 C to $1500 \mathrm{C}$ ). The porosity of chars and pyrolyzed coals \\ significantly increased during annealing at temperatures below $1373 \mathrm{~K}(1100 \mathrm{C})$ due to volatile matter \\ release. Further increasing of the annealing temperature from $1373 \mathrm{~K}$ to $1773 \mathrm{~K}$ ( $1100 \mathrm{C}$ to $1500 \mathrm{C}$ ) \\ caused marginal porosity evolution. The porosity of cokes was not affected by annealing at temperatures \\ below $1573 \mathrm{~K}(1300 \mathrm{C}$ ) and slightly increased in the temperature range 1573 to $1773 \mathrm{~K}$ (1300 C to 1500 \\ C). The increase in the porosity of chars and pyrolyzed coals during annealing at temperatures $1373 \mathrm{~K}$ to \\ $1773 \mathrm{~K}(1100 \mathrm{C}$ to $1500 \mathrm{C})$, and cokes at $1573 \mathrm{~K}$ to $1773 \mathrm{~K}(1300 \mathrm{C}$ to $1500 \mathrm{C})$, was a result of reactions \\ with oxides of their mineral phases. Annealing had a marginal effect on the pore shape (Feret ratio) of \\ carbonaceous materials, but enlarged the pore size of chars and pyrolyzed coals and decreased their pore \\ density.

\section{Disciplines} \\ Engineering | Science and Technology Studies

\section{Publication Details} \\ Xing, X., Zhang, G., Dell'Amico, M., Ciezki, G., Meng, Q. \& Ostrovski, O. (2013). Effect of annealing on \\ properties of carbonaceous materials. Part II: porosity and pore geometry. Metallurgical and Materials \\ Transactions B: Process Metallurgy and Materials Processing Science, 44 (4), 862-869.

\section{Authors} \\ Xing Xing, Guangqing Zhang, Mark Dell'Amico, George Ciezki, Qingbo Meng, and Oleg Ostrovski
}




\title{
Effect of Annealing on Properties of Carbonaceous Materials. Part II: Porosity and Pore Geometry
}

\author{
XING XING, GUANGQING ZHANG, MARK DELL'AMICO, GEORGE CIEZKI, \\ QINGBO MENG, and OLEG OSTROVSKI
}

\begin{abstract}
The pore structure of carbonaceous materials was studied using image analysis. The effect of annealing on the porosity and pore geometry of cokes, chars, and pyrolyzed coals (laboratory chars) was examined in the temperature range of $973 \mathrm{~K}$ to $1773 \mathrm{~K}\left(700{ }^{\circ} \mathrm{C}\right.$ to $\left.1500{ }^{\circ} \mathrm{C}\right)$. The porosity of chars and pyrolyzed coals significantly increased during annealing at temperatures below $1373 \mathrm{~K}\left(1100^{\circ} \mathrm{C}\right)$ due to volatile matter release. Further increasing of the annealing temperature from $1373 \mathrm{~K}$ to $1773 \mathrm{~K}\left(1100{ }^{\circ} \mathrm{C}\right.$ to $\left.1500{ }^{\circ} \mathrm{C}\right)$ caused marginal porosity evolution. The porosity of cokes was not affected by annealing at temperatures below $1573 \mathrm{~K}\left(1300{ }^{\circ} \mathrm{C}\right)$ and slightly increased in the temperature range 1573 to $1773 \mathrm{~K}\left(1300{ }^{\circ} \mathrm{C}\right.$ to $\left.1500{ }^{\circ} \mathrm{C}\right)$. The increase in the porosity of chars and pyrolyzed coals during annealing at temperatures $1373 \mathrm{~K}$ to $1773 \mathrm{~K}\left(1100{ }^{\circ} \mathrm{C}\right.$ to $\left.1500{ }^{\circ} \mathrm{C}\right)$, and cokes at $1573 \mathrm{~K}$ to $1773 \mathrm{~K}\left(1300{ }^{\circ} \mathrm{C}\right.$ to $\left.1500{ }^{\circ} \mathrm{C}\right)$, was a result of reactions with oxides of their mineral phases. Annealing had a marginal effect on the pore shape (Feret ratio) of carbonaceous materials, but enlarged the pore size of chars and pyrolyzed coals and decreased their pore density.
\end{abstract}

DOI: $10.1007 / \mathrm{s} 11663-013-9854-4$

(C) The Minerals, Metals \& Materials Society and ASM International 2013

\section{INTRODUCTION}

SubMERGED electrical arc furnace is a major process in the industrial production of ferroalloys, in which metal oxides are reduced by carbonaceous materials. To reduce the production cost, a variety of carbonaceous materials are used including cokes, chars, and coals. As carbonaceous materials are the only solid materials in the lower region of the submerged electric arc furnace (coke bed zone), they are required to have good mechanical strength to insure good permeability of liquid and gas phases passing the burden.

The mechanical strength of carbonaceous materials strongly depends on the pore structure. ${ }^{[1-4]}$ The pore structure of carbonaceous materials has been intensively studied, ${ }^{[5-7]}$ with a focus on its evolution during carbonization of coals. Hays et al. ${ }^{[5]}$ examined its evolution during pyrolysis of coals. Tomeczek and Gil ${ }^{[6]}$ studied its evolution in the high pressure pyrolysis process and observed that both porosity and volatile release

XING XING, Postdoctoral Fellow, and OLEG OSTROVSKI, Professor, are with the School of Materials Science and Engineering, University of New South Wales, Sydney, NSW 2052, Australia. Contact e-mail: x.xing@unsw.edu.au GUANGQING ZHANG, Lecturer, is with the School of Mechanical, Materials \& Mechatronic Engineering, University of Wollongong, Wollongong, NSW 2522. MARK DELL'AMICO, Project Scientist, is with the CSIRO Energy Centre, 10 Murray Dwyer Circuit, Steel River Estate, Mayfield West, NSW 2304. GEORGE CIEZKI, Manager Production Planning \& Smelting Manganese, is with the Tasmanian Electro Metallurgical Company, PO Box 164, George Town, TAS 7253, Australia. QINGBO MENG, Vice-President, is with the Sinosteel Anshan Research Institute of Thermo-Energy Co., Ltd., Anshan, Liaoning, China.

Manuscript submitted February 14, 2013.

Article published online April 30, 2013. decreased with increasing pyrolysis pressure. Heating in a furnace strongly affects the pore structure of carbonaceous materials. However, only a few papers studied the effect of heat treatment on the pore structure of carbonaceous materials, ${ }^{[8,9]}$ especially under the conditions of submerged electrical arc furnaces. Gomez-Serrano et al. ${ }^{[9]}$ examined the effect of heat treatment in the temperature range of $623 \mathrm{~K}$ to $1123 \mathrm{~K}$ $\left(350{ }^{\circ} \mathrm{C}\right.$ to $\left.850{ }^{\circ} \mathrm{C}\right)$ using gas absorption and found that total porosity and microporosity developed with increasing heat treatment temperature in the temperature range of $623 \mathrm{~K}$ to $1023 \mathrm{~K}\left(350{ }^{\circ} \mathrm{C}\right.$ to $\left.750{ }^{\circ} \mathrm{C}\right)$. At higher temperature, total porosity and microporosity reduced with further increase of temperature due to micropore narrowing and pore closing. ${ }^{[10]}$ Senneca et al. ${ }^{[8]}$ studied the effect of heat treatment on micropore volume using porosimetric analysis and found that the micropore volume of carbonaceous materials increased significantly after heat treatment at $1173 \mathrm{~K}\left(900{ }^{\circ} \mathrm{C}\right)$, followed by a significant decrease with further increase of temperature. The measurement of micropore volume with porosimetric analysis suffers from the limitations of some micropores being inaccessible for $\mathrm{CO}_{2}$ molecules, and the pore accessibility can also be reduced by the phase changes of mineral matter during heat treatment. ${ }^{[11]}$ Moreover, pore geometry parameters cannot be quantitatively studied by porosimetric analyses.

Image analysis provides a reliable method to quantify pore structure including both porosity and pore geometry parameters; the results of image analysis have been correlated with coke strength. ${ }^{[12-14]}$ Patrick et al. ${ }^{[13]}$ intensively studied the pore structure with image analysis and observed good agreement of the porosity obtained from image analysis with that calculated from 
measurements of real and apparent densities. In their study, 30 to 40 different areas were examined to obtain reliable values of average porosity.

This paper studies the effect of heat treatment on the pore structure of carbonaceous materials (cokes, chars, and pyrolyzed coals) in the temperature range of $973 \mathrm{~K}$ to $1773 \mathrm{~K}\left(700{ }^{\circ} \mathrm{C}\right.$ to $\left.1500{ }^{\circ} \mathrm{C}\right)$ using image analysis and discusses the mechanisms of the pore structure evolution.

\section{EXPERIMENTAL}

The carbonaceous materials used in this study were supplied by Tasmanian Electro Metallurgical Company (TEMCO), Australia, and METALLOYS, South Africa; they included three coke samples, three char samples, and three coal samples. The proximate and petrographic analyses were completed by Sinosteel Anshan Research Institute of Thermo-energy Co., Ltd., China, in compliance with Chinese National Standards. The results of these analyses were reported previously. ${ }^{[15]}$

The coal samples were processed at the CSIRO Energy Centre in an $8-\mathrm{kg}$ retort furnace at $973 \mathrm{~K}\left(700^{\circ} \mathrm{C}\right)$ to remove volatile matter and obtain laboratory char samples (pyrolyzed coals). Approximately $200 \mathrm{~g}$ of coke, char, and pyrolyzed coal with a particle size of 19 to $21 \mathrm{~mm}$ was heat treated in a graphite furnace under argon atmosphere for 2 hours at $973 \mathrm{~K}, 1173 \mathrm{~K}$, $1373 \mathrm{~K}, 1573 \mathrm{~K}$, or $1773 \mathrm{~K}\left(700{ }^{\circ} \mathrm{C}, 900{ }^{\circ} \mathrm{C}, 1100^{\circ} \mathrm{C}\right.$, $1300{ }^{\circ} \mathrm{C}$, or $1500{ }^{\circ} \mathrm{C}$ ).

Sixty samples were mounted in epoxy resin blocks and polished to provide samples for image analysis. Care was taken to achieve a well-polished surface and avoid damage of the coke pore wall during polishing. At least 60 images were captured on 60 samples of each type of carbonaceous material by a Nikon Model EPIPHOT 200 microscope with a Nikon digital camera. Since the large pores were of most interest, a low power objective lens (magnification 5 times) was used under which small pores $(<12 \mu \mathrm{m})$ were invisible.

The captured images were binarized using image analysis software ImageJ developed by NIH. After binarization, the pores and walls of the cokes and chars were represented by black and white areas, respectively. The porosity of carbonaceous materials was calculated using ImageJ as a fraction of the black area.

Table I. Pore Geometry Parameters of Carbonaceous Materials

\begin{tabular}{ll}
\hline Parameter & Description \\
\hline Feret ratio $=\frac{\mathrm{a}}{\mathrm{b}}$ & the shape of a pore described by the ratio of \\
Feret breadth to Feret length
\end{tabular}

Equivalent circle diameter

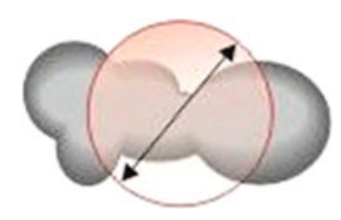

Cross section area

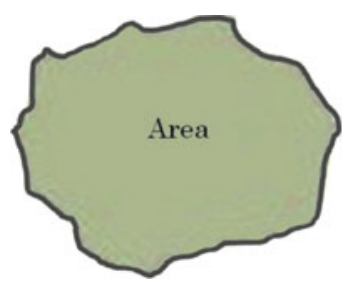

Pore density

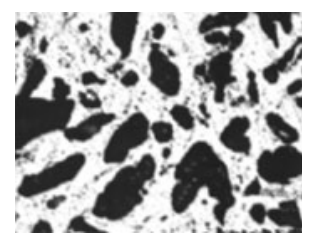

the diameter of the circle that has the same area as the feature

size of the pore quantified using the average area

the number of pores in unit area $\left(\mathrm{mm}^{-2}\right)$. 
Pore geometry parameters were determined by LAS Image Analysis software developed by Leica. Table I lists the pore geometry parameters determined in this study.

The mineral phases in the carbonaceous materials were identified using X-ray diffraction (XRD) analysis. XRD spectra of powdered samples were obtained using a Philips X'Pert Multipurpose X-ray Diffraction System (MPD). Copper $\mathrm{K} \alpha$ radiation ( $45 \mathrm{kV}, 40 \mathrm{~mA}$ ) was used as the X-ray source. Samples were scanned with $2 \theta$ in the range of 10 to $70 \mathrm{deg}$ with a step size of $0.02 \mathrm{deg}$ and 0.6 seconds of scanning time at each step. Mineral phases were identified using X'Pert HighScore Plus software.

\section{EFFECT OF HEAT TREATMENT ON POROSITY OF CARBONACEOUS MATERIALS}

The porosity of the original carbonaceous materials and after annealing at different temperatures is presented in Table II. Relative standard deviation (RSD) of the porosity measurement is shown in brackets.

The porosity of the original cokes was in the range of 47 to 51 pet. Heat treatment at $1573 \mathrm{~K}\left(1300^{\circ} \mathrm{C}\right)$ caused a slight increase of porosity. After the 2-h annealing, the increase in porosity of the cokes was more noticeable; the porosity rose to approximately 53 pct.

The porosity of the original chars changed in a broad interval, from 19 pet for Char 3 to 69 pet for Char 1 . Heat treatment of chars at $1373 \mathrm{~K}\left(1100{ }^{\circ} \mathrm{C}\right)$ caused a 15 to 20 pct increase of porosity. Porosity increased further with increasing of temperature to $1773 \mathrm{~K}\left(1500{ }^{\circ} \mathrm{C}\right)$, which was not significant.

The porosity of the originally pyrolyzed coals was 19 to 23 pct, which was formed during the char production at $973 \mathrm{~K}\left(700{ }^{\circ} \mathrm{C}\right)$. A sharp increase of 38 pct in porosity was found for Coal 1 and Coal 3, while the porosity of Coal 2 increased by 28 pct after 2 hours of annealing at $973 \mathrm{~K}\left(700^{\circ} \mathrm{C}\right)$, showing that the pyrolysis during preparation of the pyrolyzed chars from coals was far from complete. Further annealing of the pyrolyzed coals increased porosity with decreasing increment. The effect of increasing annealing temperature on porosity was stronger in the temperature range $973 \mathrm{~K}$ to $1373 \mathrm{~K}$ $\left(700{ }^{\circ} \mathrm{C}\right.$ to $\left.1100{ }^{\circ} \mathrm{C}\right)$ than in the temperature range of $1373 \mathrm{~K}$ to $1773 \mathrm{~K}\left(1100{ }^{\circ} \mathrm{C}\right.$ to $\left.1500{ }^{\circ} \mathrm{C}\right)$.

Heat treatment promoted the porosity evolution of all carbonaceous materials. Overall, the RSD of the coke samples was much smaller than the original char and pyrolyzed coal samples and did not change much along with annealing, reflecting the homogeneous feature of cokes. Except Char 2, the original char and pyrolyzed coal samples had significantly bigger RSDs in the porosity measurement, which is a strong indication of the heterogeneity of these samples. Char 2 was more uniform and more completely pyrolyzed in comparison with the other chars and pyrolyzed coals. The RSD of porosity determination decreased with increasing annealing temperature, approaching that of cokes along with completion of pyrolysis.

The pore geometry parameters of the original cokes, chars, and pyrolyzed coals, Feret (aspect) ratio, surface area, equivalent circle diameter, and pore density, are presented in Table III. Table IV presents the pore parameters of the carbonaceous materials heat treated at $1773 \mathrm{~K}\left(1500^{\circ} \mathrm{C}\right)$.

Only pores with a size above $1000 \mu \mathrm{m}^{2}$ are considered in Tables III and IV. Smaller pores are not expected to have significant effect on the mechanical properties of carbonaceous materials. ${ }^{[16]}$

Table II. Porosity of Carbonaceous Materials Before and After 2-hour Annealing at Different Temperatures (percentage)

\begin{tabular}{lccccc}
\hline & Original & $973 \mathrm{~K}\left(700{ }^{\circ} \mathrm{C}\right)$ & $1373 \mathrm{~K}\left(1100{ }^{\circ} \mathrm{C}\right)$ & $1573 \mathrm{~K}\left(1300{ }^{\circ} \mathrm{C}\right)$ & $1773 \mathrm{~K}\left(1500{ }^{\circ} \mathrm{C}\right)$ \\
\hline Coke 1 & $46.8(0.115) *$ & - & - & $48.6(0.110)$ & $52.2(0.094)$ \\
Coke 2 & $51.4(0.133)$ & - & - & $51.1(0.114)$ & $53.2(0.139)$ \\
Coke 3 & $51.0(0.148)$ & - & $53.6(0.289)$ & - & $53.4(0.119)$ \\
Char 1 & $43.7(0.333)$ & - & $79.5(0.157)$ & - & $55.6(0.264)$ \\
Char 2 & $69.0(0.184)$ & - & $23.8(0.454)$ & - & $82.6(0.102)$ \\
Char 3 & $18.8(0.483)$ & $59.4(0.106)$ & $63.6(0.114)$ & - & $64.6(0.440)$ \\
Coal 1 & $21.3(0.363)$ & $46.0(0.309)$ & $59.7(0.217)$ & - & $696)$ \\
Coal 2 & $19.0(0.365)$ & $60.5(0.220)$ & $69.0(0.156)$ & $0.195)$ \\
Coal 3 & $22.7(0.392)$ & & & $71.7(0.116)$ \\
\hline
\end{tabular}

* Relative standard deviation of measurement.

Table III. Pore Geometry Parameters of Original Carbonaceous Materials

\begin{tabular}{|c|c|c|c|c|c|c|c|c|}
\hline & Coke 1 & Coke 2 & Coke 3 & Char 1 & Char 2 & Coal 1 & Coal 2 & Coal 3 \\
\hline Feret ratio (pct) & 56.7 & 57.5 & 57.2 & 52.4 & 51.6 & 58.8 & 52.9 & 58.8 \\
\hline Mean area $\left(\mu \mathrm{m}^{2}\right)$ & 14,002 & 18,859 & 19,231 & 12,830 & 14,927 & 21,030 & 9700 & 4555 \\
\hline Equivalent circle diameter, $(\mu \mathrm{m})$ & 104.7 & 115.5 & 114.1 & 94.7 & 105.9 & 115.2 & 91.3 & 68.7 \\
\hline Pore density (pores $\mathrm{mm}^{-2}$ ) & 31.9 & 25.8 & 26.9 & 41.5 & 43.5 & 26.8 & 51.0 & 86.8 \\
\hline
\end{tabular}

Only pores with an area of more than $1000 \mu \mathrm{m}^{2}$ have been included in this table. 
Feret ratio, the shape factor, of all carbonaceous materials varied between 52 and 59 pct. After 2 hours of annealing at $1773 \mathrm{~K}\left(1500{ }^{\circ} \mathrm{C}\right)$, no significant variation in pore shape was observed.

Mean pore cross-sectional area of the original cokes, chars, and pyrolyzed coals was in the range of 4555 to $21,030 \mu \mathrm{m}^{2}$ depending on the type of carbonaceous material. The mean pore diameter varied from 68.7 to $115.5 \mu \mathrm{m}$. Pyrolyzed Coal 3 had the smallest pore size, with a $68.7-\mu \mathrm{m}$ pore diameter and $4555-\mu \mathrm{m}^{2}$ mean surface area, while Coke 2, Coke 3, and pyrolyzed Coal 1 had a larger pore size. Pore size of the original cokes increased slightly after heat treatment at $1773 \mathrm{~K}$ $\left(1500{ }^{\circ} \mathrm{C}\right)$. However, more significant enlargement of pore size caused by annealing was observed in chars and pyrolyzed coals. Over $22 \mu \mathrm{m}$ increase in diameter was found in Char 2 and pyrolyzed Coal 3; the smallest pore enlargement was $9.6 \mu \mathrm{m}$ for Char 1 .

Pore density of the original cokes varied in the range of 25.8 to 31.9 pores $\mathrm{mm}^{-2}$ and annealing at $1773 \mathrm{~K}$ $\left(1500{ }^{\circ} \mathrm{C}\right)$ had a slight effect on their pore density. Pore density of chars and pyrolyzed coals significantly decreased after annealing as a result of enlargement of pores.

The change in the pore geometry parameters of cokes upon heat treatment was marginal. However, annealing caused significant changes in the pore geometry parameters of chars and pyrolyzed coals. These results are consistent with porosity development of corresponding carbonaceous materials.

\section{FACTORS AFFECTING POROSITY DEVEL- OPMENT IN HEAT TREATMENT}

\section{A. Chars and Pyrolyzed Coals}

Significant porosity increase during annealing of chars and coals took place at temperatures below $1373 \mathrm{~K}$ $\left(1100{ }^{\circ} \mathrm{C}\right)$. Figure 1 presents images of a sample of original Char 2 and the same sample annealed at $1373 \mathrm{~K}$ $\left(1100{ }^{\circ} \mathrm{C}\right)$. In Figure $1(\mathrm{a})$, the pore walls are relatively thick, and carbonaceous matrices almost with no pores can be observed. After annealing at $1373 \mathrm{~K}\left(1100{ }^{\circ} \mathrm{C}\right)$ (Figure 1(b)), some small pores connected together to form larger pores and some new pores appeared in the carbonaceous matrices observed in Figure 1(a). Therefore, the porosity of char was predominantly developed by the connection of existing pores and generation of new pores. These changes result in a decrease in pore density and increase in pore size (Table IV) accompanying the increase of porosity.

The porosity development in the process of heat treatment of chars and pyrolyzed coals is related to the release of volatile matter. Indeed, the volatile matter release and the porosity development in heat treatment of chars and coals exhibit similar trends as both of them occur on annealing at temperatures below $1373 \mathrm{~K}$ $\left(1100{ }^{\circ} \mathrm{C}\right)$. The change in volatile matter ${ }^{[15]}$ and porosity of chars and pyrolyzed coals after heating at $1373 \mathrm{~K}$ $\left(1100{ }^{\circ} \mathrm{C}\right)$ is shown in Figure 2. Good correlation between these two parameters indicates that porosity development in chars and coals was closely related to

Table IV. Pore Geometry Parameters of Carbonaceous Materials Annealed at $1773 \mathrm{~K}\left(1500{ }^{\circ} \mathrm{C}\right)$ for $2 \mathrm{~h}$

\begin{tabular}{lllllllll}
\hline & Coke 1 & Coke 2 & Coke 3 & Char 1 & Char 2 & Coal 1 & Coal 2 & Coal 3 \\
\hline Feret ratio $(\mathrm{pct})$ & 57.1 & 58.1 & 57.4 & 55.2 & 52.4 & 57.4 & 50.2 & 57.4 \\
Area $\left(\mu \mathrm{m}^{2}\right)$ & 15,018 & 19,590 & 19,946 & 16,128 & 22,736 & 26,939 & 15,753 & 9029 \\
Equivalent circle diameter $(\mu \mathrm{m})$ & 106.3 & 119.4 & 119.8 & 104.3 & 128.6 & 128.9 & 107.2 & 93.8 \\
Pore density (pores $\left.\mathrm{mm}^{-2}\right)$ & 32.8 & 25.5 & 26.3 & 36.2 & 31.8 & 23.3 & 37.1 & 68.1 \\
\hline
\end{tabular}

Only pores with an area of more than $1000 \mu \mathrm{m}^{2}$ have been included in this table.

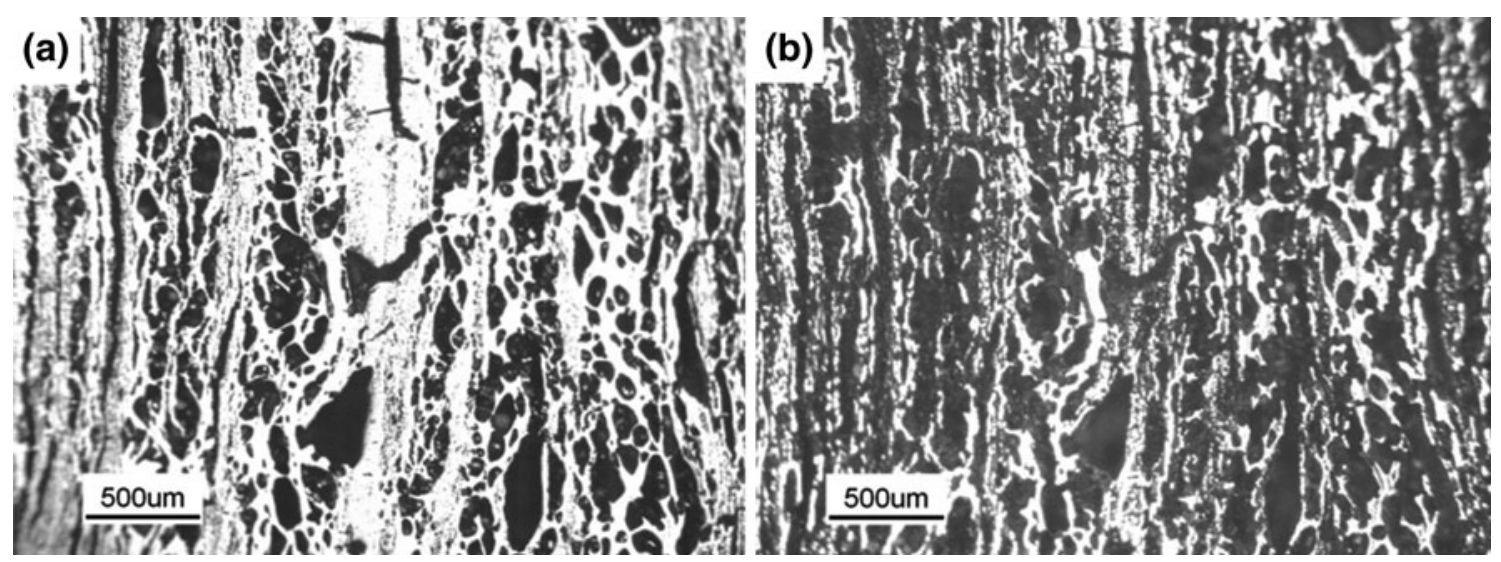

Fig. 1-Images of $(a)$ a sample of original Char 2 and $(b)$ the same sample annealed at $1373 \mathrm{~K}\left(1100{ }^{\circ} \mathrm{C}\right)$. 


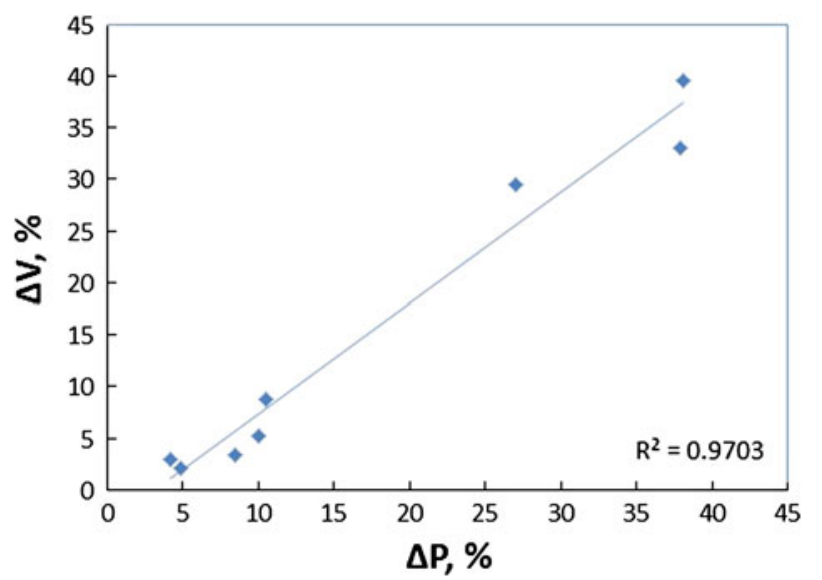

Fig. 2 - Correlation between volatile matter release $(\Delta V)$ and porosity evolution $(\Delta P)$ for the pyrolyzed coals and chars annealed at $1373 \mathrm{~K}\left(1100{ }^{\circ} \mathrm{C}\right)$.

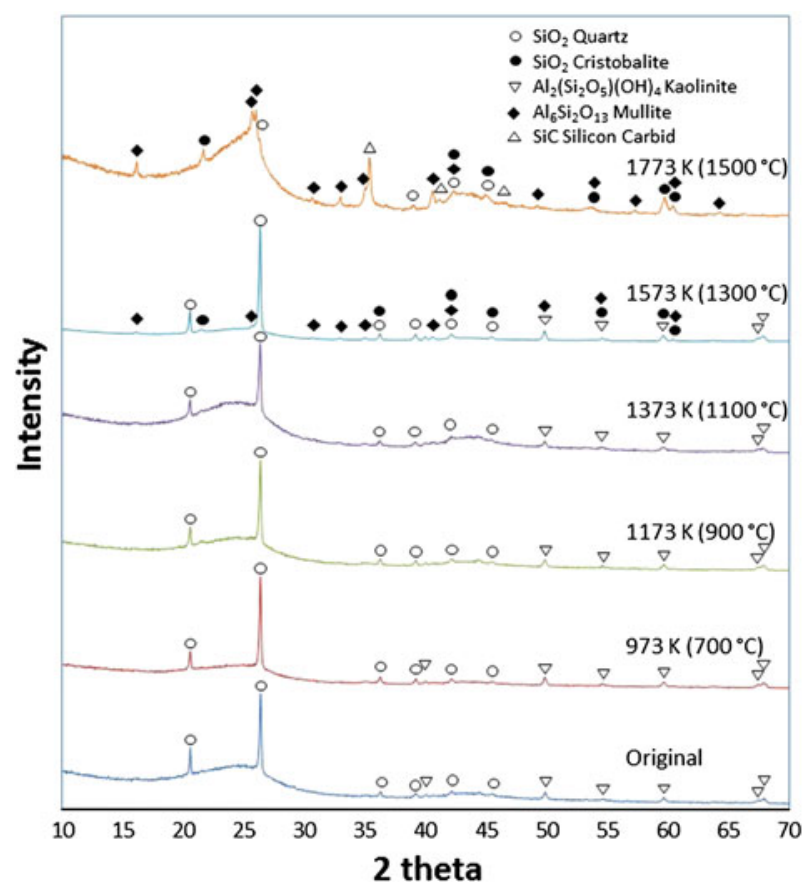

Fig. 3-XRD patterns of the original and annealed Char 1.

the volatile matter release. The deviation of the line from the origin in Figure 2 cannot be completely attributed to the experimental error of measurement of porosity and volatile matter. Volatile matter release is a major but not necessarily the only factor affecting porosity change. One factor is that fine pores invisible in the original samples were not counted in porosity measurement, but became measurable when combined with nearby fine or coarse pores. Another factor is the densification of the wall matrix along with carbonization of the carbonaceous material.

When the annealing temperature was increased to above $1373 \mathrm{~K}\left(1100^{\circ} \mathrm{C}\right)$, release of volatile matter in chars and pyrolyzed coals was close to completion;

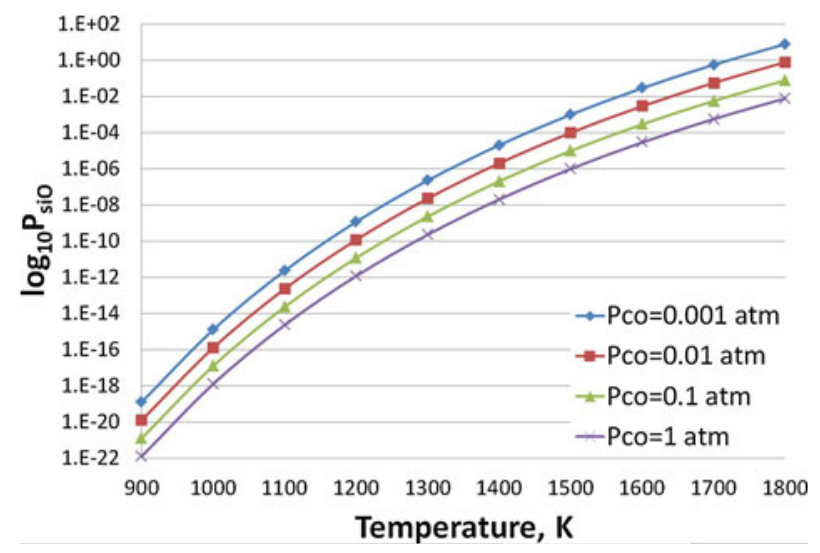

Fig. 4-Equilibrium partial pressure of $\mathrm{SiO} v s$ temperature for reaction [1].

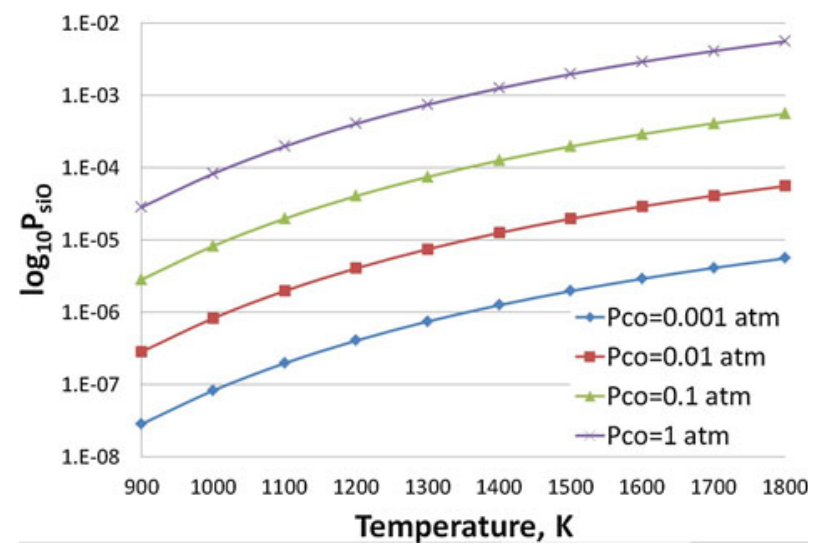

Fig. 5-Equilibrium partial pressure of $\mathrm{SiO} v s$ temperature for reaction [2].

however, their porosity increased further with growing annealing temperature, although this increase is insignificant. This increase is attributed to the reactions of minerals with carbon in carbonaceous materials.

XRD analysis showed that the major phases of mineral matter in the original chars were kaolinite $\mathrm{Al}_{2}\left(\mathrm{Si}_{2} \mathrm{O}_{5}\right)(\mathrm{OH})_{4}$ and quartz $\mathrm{SiO}_{2}$. Marcasite $\mathrm{FeS}_{2}$ was also present in Char 3 with low content. Other minerals were not identified due to their low concentrations. XRD spectra of original and annealed samples of Char 1 are presented in Figure 3. The broad band at $25.8 \mathrm{deg}$ $(2 \theta)$ is the (002) carbon peak.

According to Figure 3, no significant changes in the phase composition take place during annealing up to $1373 \mathrm{~K}\left(1100{ }^{\circ} \mathrm{C}\right)$. Kaolinite decomposed to cristobalite $\mathrm{SiO}_{2}$ and mullite $\mathrm{Al}_{6} \mathrm{Si}_{2} \mathrm{O}_{13}$ when the char was annealed at temperatures higher than $1373 \mathrm{~K}\left(1100{ }^{\circ} \mathrm{C}\right)$. When the annealing temperature was increased to $1773 \mathrm{~K}$ $\left(1500{ }^{\circ} \mathrm{C}\right)$, the transformation of kaolinite to cristobalite and mullite was close to completion. At $1773 \mathrm{~K}$ $\left(1500{ }^{\circ} \mathrm{C}\right)$, quartz in the original chars and cristobalite formed from kaolinite were reduced to $\mathrm{SiO}$ and silicon carbide $\mathrm{SiC}$ by reactions 


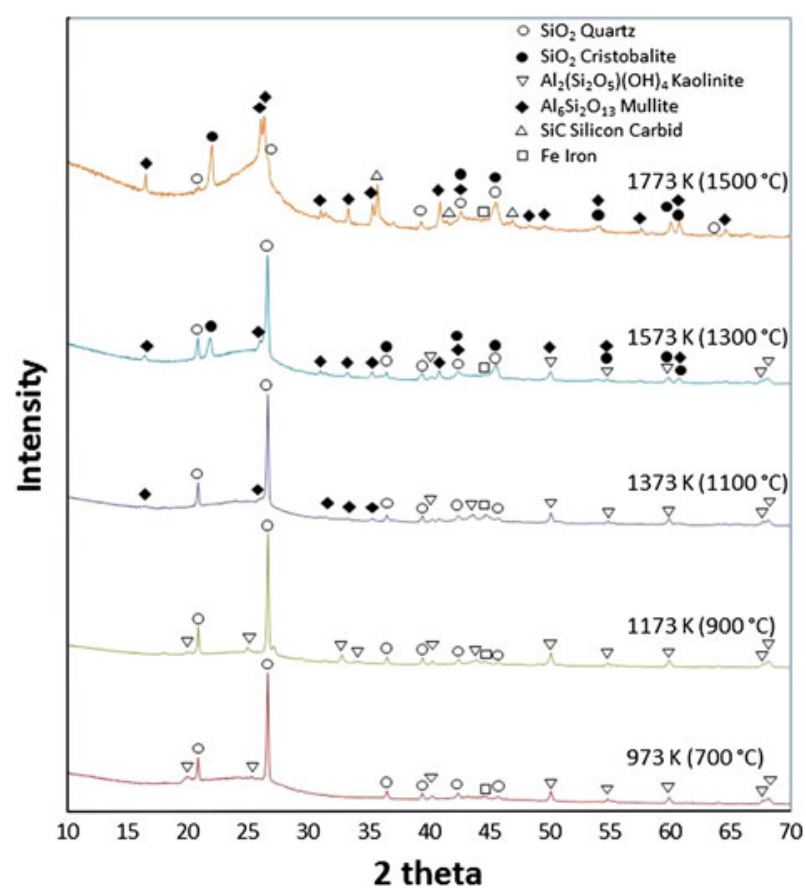

Fig. 6-XRD patterns of pyrolyzed Coal 2 annealed at different temperatures.

$$
\begin{aligned}
& \mathrm{SiO}_{2}(\mathrm{~s})+\mathrm{C}(\mathrm{s})=\mathrm{SiO}(\mathrm{g})+\mathrm{CO}(\mathrm{g}), \\
& \Delta G^{0}=680.8-0.3386 T \\
& \mathrm{SiO}(\mathrm{g})+2 \mathrm{C}(\mathrm{s})=\mathrm{SiC}(\mathrm{s})+\mathrm{CO}(\mathrm{g}), \\
& \Delta G^{0}=-78.845+0.0006 T
\end{aligned}
$$

For reaction [1], the equilibrium partial pressure of $\mathrm{SiO}$ as a function of temperature and partial pressure of $\mathrm{CO}$ in the system is shown in Figure 4. At a constant partial pressure of $\mathrm{CO}$, the equilibrium partial pressure of $\mathrm{SiO}$ increases with the increase in temperature. At constant temperature, the equilibrium partial pressure of $\mathrm{SiO}$ increases with the decrease in the partial pressure of $\mathrm{CO}$. When the temperature increases to $1773 \mathrm{~K}$ $\left(1500{ }^{\circ} \mathrm{C}\right)$, the equilibrium partial pressure of $\mathrm{SiO}\left(P_{\mathrm{SiO}}\right)$ is $4.25 \times 10^{-3} \mathrm{~atm}$ for the partial pressure of $\mathrm{CO}$ of $1 \mathrm{~atm} ; P_{\mathrm{SiO}}$ increases to $4.24 \mathrm{~atm}$ when $P_{\mathrm{CO}}$ decreases to $0.001 \mathrm{~atm}$. During heat treatment of chars in flowing argon, the formed $\mathrm{CO}$ was continuously removed from the system; therefore, the partial pressure of $\mathrm{CO}$ was low enough to make reaction [1] thermodynamically possible at $1773 \mathrm{~K}\left(1500{ }^{\circ} \mathrm{C}\right)$.
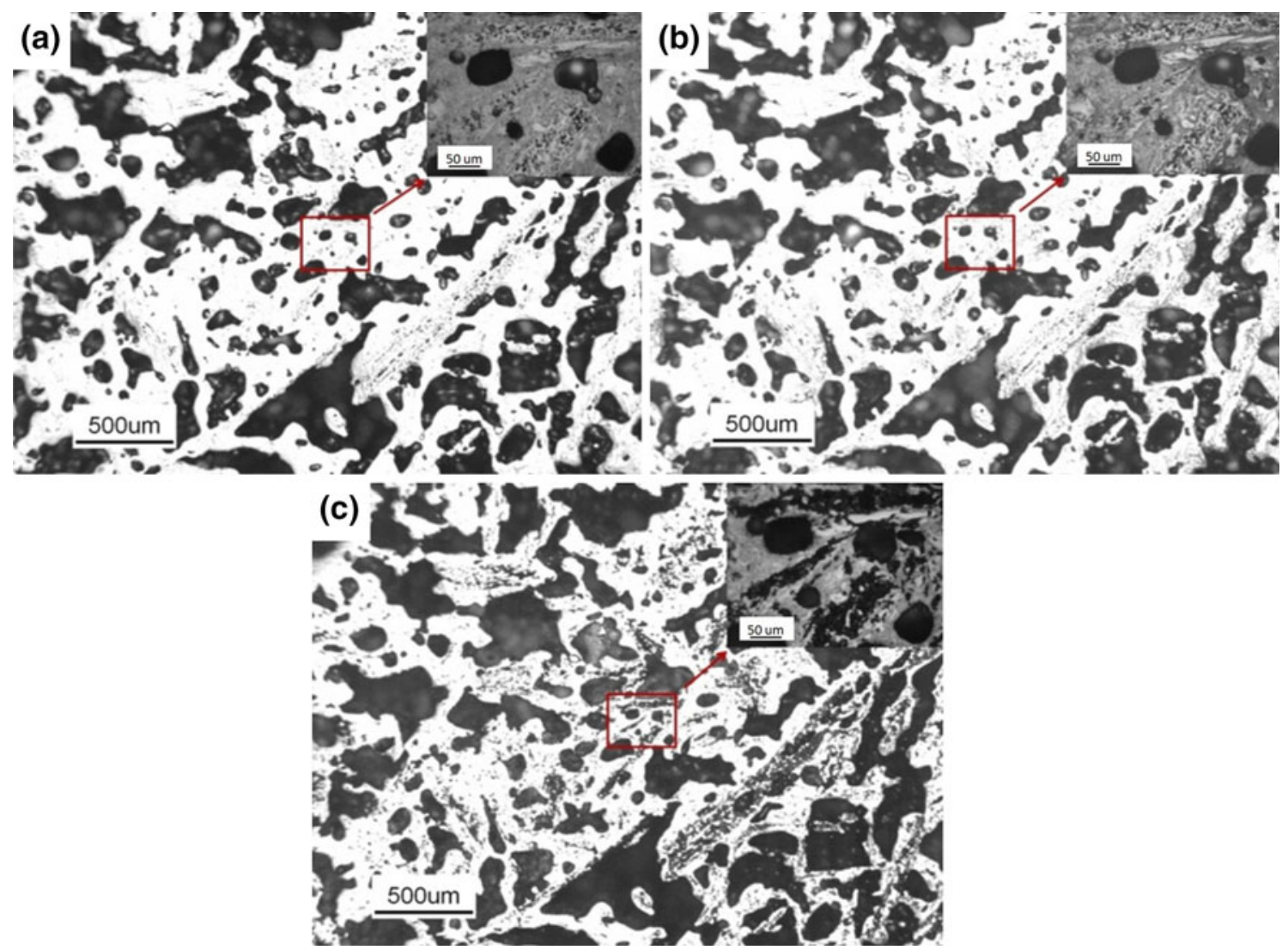

Fig. 7-Images of a sample of original Coke $1(a)$ and the same sample annealed at $1373 \mathrm{~K}\left(1100{ }^{\circ} \mathrm{C}\right)(b)$ and $1773 \mathrm{~K}\left(1500{ }^{\circ} \mathrm{C}\right)(c)$. 
The standard Gibbs free energy change for reaction [2] is negative at $1773 \mathrm{~K}\left(1500{ }^{\circ} \mathrm{C}\right)$. The equilibrium partial pressure of $\mathrm{SiO}$ as a function of temperature and partial pressure of CO in the system is shown in Figure 5. This plot shows the minimum (equilibrium) $P_{\mathrm{SiO}}$ needed for formation of $\mathrm{SiC}$. At $1773 \mathrm{~K}\left(1500{ }^{\circ} \mathrm{C}\right)$, the equilibrium partial pressure of $\mathrm{SiO}$ is $5.16 \times 10^{-6} \mathrm{~atm}$ when partial pressure of $\mathrm{CO}$ is $0.001 \mathrm{~atm}$, and $P_{\mathrm{SiO}}=5.16 \times 10^{-3} \mathrm{~atm}$ when $P_{\mathrm{CO}}=1 \mathrm{~atm}$. Therefore, reaction [2] is also thermodynamically feasible at $1773 \mathrm{~K}\left(1500{ }^{\circ} \mathrm{C}\right)$.

Conversion of quartz to silicon carbide was confirmed by XRD analysis of mineral matter after annealing; see Figure 3.

Change of the mineral composition of pyrolyzed coals with annealing temperature is presented in Figure 6. Mineral phases in pyrolyzed coals included predominantly quartz $\mathrm{SiO}_{2}$ and kaolinite $\mathrm{Al}_{2}\left(\mathrm{Si}_{2} \mathrm{O}_{5}\right)(\mathrm{OH})_{4}$. Similar to mineral phases in chars, kaolinite decomposed to cristobalite and mullite when the annealing temperature was increased to above $1373 \mathrm{~K}\left(1100{ }^{\circ} \mathrm{C}\right)$. This reaction was completed when heat treatment temperature increased to $1773 \mathrm{~K}\left(1500{ }^{\circ} \mathrm{C}\right)$. At $1773 \mathrm{~K}$ $\left(1500{ }^{\circ} \mathrm{C}\right)$, quartz and cristobalite were reduced to silicon carbide. The reduction of silica increased the char porosity.

\section{B. Cokes}

Figure 7 presents images of a sample of original Coke 1 , and the same sample annealed at $1373 \mathrm{~K}$ and $1773 \mathrm{~K}$ $\left(1100{ }^{\circ} \mathrm{C}\right.$ and $\left.1500{ }^{\circ} \mathrm{C}\right)$. No visible change in pore structure was observed in Coke 1 after annealing at $1373 \mathrm{~K}\left(1100^{\circ} \mathrm{C}\right)$. When annealing temperature was $1773 \mathrm{~K}\left(1500{ }^{\circ} \mathrm{C}\right)$, some of the pores connected together

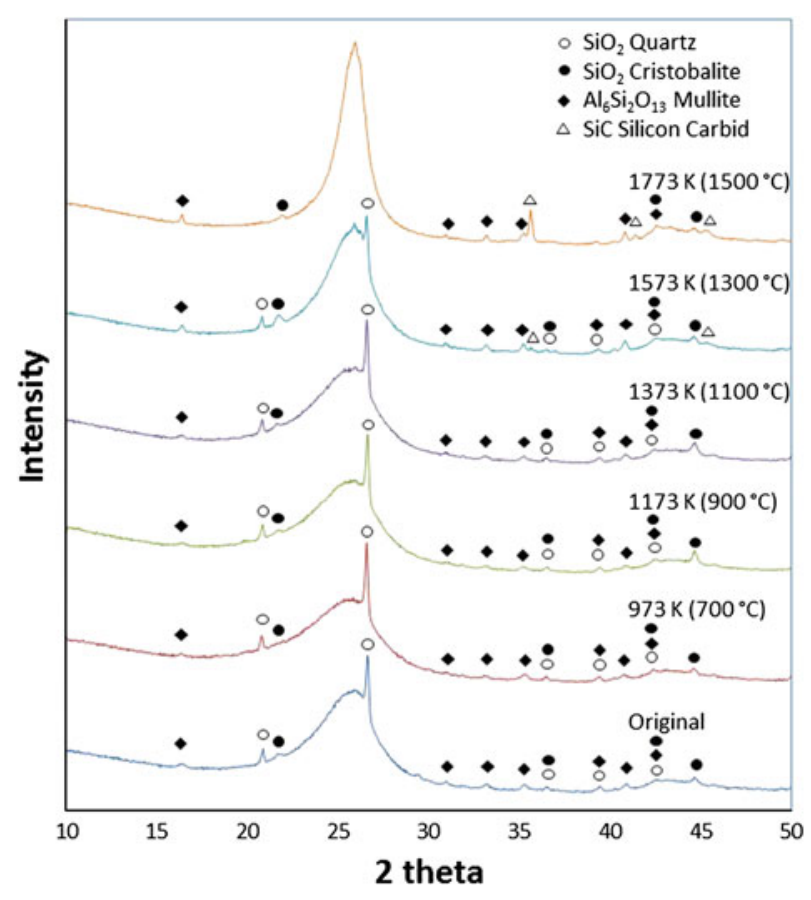

Fig. 8-XRD patterns of original and annealed Coke 1. to form larger pores, and new pores were formed. The generation of new pores and the connection of existing pores to larger pores increased coke porosity.

In the coke-making process, coking coal is exposed to high temperatures (above $1273 \mathrm{~K}\left(1000{ }^{\circ} \mathrm{C}\right)$ ) for 16 to 18 hours. As a result, the content of volatile matter in the cokes was much smaller than in char and particularly in coal. The change in the volatile matter in the annealing processes and its effect on the coke porosity were also small. ${ }^{[15]}$ The increase in the porosity which was observed when the annealing temperature was increased to above $1573 \mathrm{~K}\left(1300{ }^{\circ} \mathrm{C}\right)$ can be attributed to the reaction of minerals in coke with carbon.

XRD spectra of cokes are presented in Figure 8. The major mineral phases of the original cokes were quartz $\mathrm{SiO}_{2}$, cristobalite $\mathrm{SiO}_{2}$, and mullite $\mathrm{Al}_{6} \mathrm{Si}_{2} \mathrm{O}_{13}$. Kaolinite, which is also a major component of chars and coals, decomposed into cristobalite $\mathrm{SiO}_{2}$ and mullite $\mathrm{Al}_{6} \mathrm{Si}_{2} \mathrm{O}_{13}$ in the coking process. With increasing annealing of temperature, mineral phases did not change until the heat treatment temperature reached $1573 \mathrm{~K}\left(1300{ }^{\circ} \mathrm{C}\right)$. At $1573 \mathrm{~K}\left(1300^{\circ} \mathrm{C}\right)$, quartz and cristobalite started reacting with carbon to form silicon carbide. When the temperature increased to $1773 \mathrm{~K}\left(1500{ }^{\circ} \mathrm{C}\right)$, all the quartz and cristobalite were reduced to $\mathrm{SiC}$, no silica being detected in the XRD spectrum.

To summarize, the development of porosity in carbonaceous materials was attributed to a combination of volatile matter release and reaction of mineral matter with carbon. Volatile matter release played a significant role in the porosity development of chars and pyrolyzed coals at relatively low temperatures. Approximately 30 pct volatile matter release during annealing of pyrolyzed coals at $973 \mathrm{~K}\left(700{ }^{\circ} \mathrm{C}\right)$ caused about 35 pct increase in porosity. With increasing of annealing temperature from $973 \mathrm{~K}$ to $1373 \mathrm{~K}\left(700{ }^{\circ} \mathrm{C}\right.$ to $\left.1100{ }^{\circ} \mathrm{C}\right)$, the porosity of chars and pyrolyzed coals increased by approximately 10 pct. The reactions of minerals with carbon took place when the annealing temperature was increased to above $1373 \mathrm{~K}\left(1100{ }^{\circ} \mathrm{C}\right)$ when volatiles release was marginal. In this temperature range, the approximately 2.5 pct increase in porosity was mainly attributed to the reaction of mineral matter with carbon.

\section{CONCLUSIONS}

The effect of annealing on the pore structure of carbonaceous materials was studied by image analysis and $\mathrm{X}$-ray diffraction. The major findings are summarized below.

1. Heat treatment increased the porosity of all carbonaceous materials. The effect of heat treatment on chars and pyrolyzed coals was higher than on cokes.

2. The porosity of chars and pyrolyzed coals significantly increased during annealing at temperatures below $1373 \mathrm{~K}\left(1100^{\circ} \mathrm{C}\right)$. The porosity of cokes was not affected by heat treatment at temperatures below 
$1573 \mathrm{~K}\left(1300{ }^{\circ} \mathrm{C}\right)$, but slightly increased in the temperature range of $1573 \mathrm{~K}$ to $1773 \mathrm{~K}\left(1300{ }^{\circ} \mathrm{C}\right.$ to $\left.1500{ }^{\circ} \mathrm{C}\right)$.

3. Annealing had a marginal influence on the pore shape (Feret ratio) of carbonaceous materials, but enlarged the pore size of chars and pyrolyzed coals and decreased their pore density.

4. The development of porosity of carbonaceous materials during heat treatment was attributed to the volatile matter release and reactions of mineral matters with carbon; volatile matter release played a major role in the porosity development.

\section{ACKNOWLEDGMENTS}

This project was financially supported by Tasmanian Electrometallurgical Company and the Australian Research Council (ARC Linkage Project LP 098493). Pyrolyzed coal samples were prepared at the CSIRO Energy Centre, Newcastle, Australia. The proximate, ultimate, and petrographic analyses were completed by Sinosteel Anshan Research Institute of Thermo-energy Co., Ltd., China.

\section{REFERENCES}

1. J.W. Patrick and A. Walker: Carbon, 1989, vol. 27 (1), pp. 117-23.

2. M.G.K. Grant, A.C.D. Chaklader, and J.T. Price: Fuel, 1991, vol. 70 (2), pp. 181-88.

3. H. Sato, J.W. Patrick, and A. Walker: Fuel, 1998, vol. 77 (11), pp. $1203-08$

4. Y. Kubota, S. Nomura, T. Arima, and K. Kato: ISIJ Int., 2011, vol. 51 (11), pp. 1800-08.

5. D. Hays, J.W. Patrick, and A. Walker: Fuel, 1976, vol. 55 (4), pp. 297-302.

6. J. Tomeczek and S. Gil: Fuel, 2003, vol. 82 (3), pp. 285-92.

7. P.K. Singla, S. Miura, R.R. Hudgins, and P.L. Silveston: Fuel, 1983, vol. 62 (6), pp. 645-48.

8. O. Senneca, P. Salatino, and S. Masi: Fuel, 1998, vol. 77 (13), pp. 1483-93.

9. V. Gomez-Serrano, J. Pastor-Villegas, C.J. Duran-Valle, and C. Valenzuela-Calahorro: Carbon, 1996, vol. 34 (4), pp. 533-38.

10. J. Pastor-Villegas, C. Valenzuela-Calahorro, A. Bernalte-Garcia, and V. Gomez-Serrano: Carbon, 1993, vol. 31 (7), pp. 1061-69.

11. S.Y. Lin, M. Hirato, and M. Horio: Energy Fuels, 1994, vol. 8 (3), pp. $598-606$

12. J.W. Patrick and A.E. Stacey: Fuel, 1975, vol. 54 (4), pp. 256-64.

13. J.W. Patrick, M.J. Sims, and A.E. Stacey: J. Microsc., 1977, vol. 109 (1), pp. 137-43.

14. J.W. Patrick, M.J. Sims, and A.E. Stacey: J. Phys. D, 1980, vol. 13 (6), pp. 937-51.

15. X. Xing: Ph.D. Thesis, School of Material Science and Engineering, University of New South Wales, 2012, pp. 71-86.

16. N. Andriopoulos, C.E. Loo, R. Dukino, and S.J. McGuire: ISIJ Int., 2003, vol. 43 (10), pp. 1528-37. 